\title{
THE ORDOVICIAN-SILURIAN TRANSITION BEDS IN THE SEAFLOOR BETWEEN GOTLAND AND HIIUMAA ISLANDS, BALTIC PROPER
}

\author{
Tom FLODEN, a Väino PUURA, ${ }^{\text {b }}$ Per SÖDERBERG, ${ }^{\text {a }}$ Igor TUULING, ${ }^{\mathrm{b}}$ \\ and Kalle SUUROJA ${ }^{\mathrm{c}}$
}

a Stockholms Universitet, Institutionen för Geologi och Geokemi (Department of Geology and Geochemistry, Stockholm University), 10691 Stockholm, Sverige (Sweden)

b Eesti Teaduste Akadeemia Geoloogia Instituut (Institute of Geology, Estonian Academy of Sciences), Estonia pst. 7, EE-0100 Tallinn, Eesti (Estonia)

c Eesti Geoloogiakeskus (Geological Survey of Estonia), Pikk 67, EE-0101 Tallinn, Eesti (Estonia)

Received July 20, 1993; accepted September 17, 1993

\begin{abstract}
High resolution continuous seismic profiles, shot during 1990-1992 between Sweden and Estonia, have provided new details of the Lower Paleozoic seismic stratigraphy and especially on the traceability of seismic reflectors. Combined with recent lithologic and biostratigraphic information from onshore drillings these findings make it now possible to perform stratigraphic interpretations on epoch rather than period level. The onshore core studies show distinct differences in the facial pattern of the upper Ordovician and especially the lower Silurian deposits between the opposite sides of the sea. On the basis of the seismic recordings both gradual and local lateral changes in the thickness and the internal structure of the seismostratigraphic units have been distinguished. An updated map of the upper Ordovician and lower Silurian outcrops on the seabed has been compiled.
\end{abstract}

Key words: Baltic Sea, Ordovician, Silurian, seismostratigraphy, geological map.

\section{INTRODUCTION}

A principal outline of the trans-Baltic correlation of the Ordovician and Silurian systems between Estonia (mainland and the islands of Hiiumaa and Saremaa) and Sweden (the islands of Gotland and Oland and the Kalmar coastal area) was given already more than 100 years ago on a cross section by Schmidt (1881). Regarding the general relationship between bottom topography and the extensions and rock types of the sedimentary strata, Martinsson (1958) published a bedrock sketch map of the northern Baltic Proper.

Marine geological investigations of the sedimentary bedrock in the northern Baltic Proper commenced at the Department of Geology, Stockholm University, in 1963 mainly in the area north of Öland, and in 1966 in the Gotland area. During the period 1963-1978 about $25000 \mathrm{~km}$ of continuous seismic reflection profiles were recorded (Flodén, 1975, $1980,1981)$. The area north-east of Gotland up to the meridian $21^{\circ} \mathrm{E}$ was covered by a nearly regular net of $\mathrm{N}-\mathrm{S}, \mathrm{NE}-\mathrm{SW}, \mathrm{NW}-\mathrm{SE}$, and $\mathrm{W}-\mathrm{E}$ 
profiles (Fig. 1). As a result, an interpretation, with maps and profiles, of the Ordovician-Silurian boundary zone NE of Gotland was given in a monograph by Flodén (1980).

In the NE part of the Baltic Proper, in the vicinity of Hiiumaa Island, occasional seismic profiling combined with bottom dredging was performed by marine geophysicists and geologists of the former Soviet Union (Kaliningrad, St. Petersburg). Combined with a small-scale study performed by the Geological Survey of Estonia, this information was used to compile an overview map in the scale of 1:500 000 (unpublished). The data mentioned above was furthermore used to compile the Geological map of the Baltic Sea, edited in Lithuania by Algimantas Grigelis (Григелис, 1991). Tarmo Kiipli (Tallinn) mentioned in 1989 (oral comm.) that, in his opinion, there was a disagreement between the interpretations of the Ordovician-Silurian boundary strata which started from Gotland in the west, on the one hand, and from the Hiiumaa-Saaremaa area in the east, on the other.

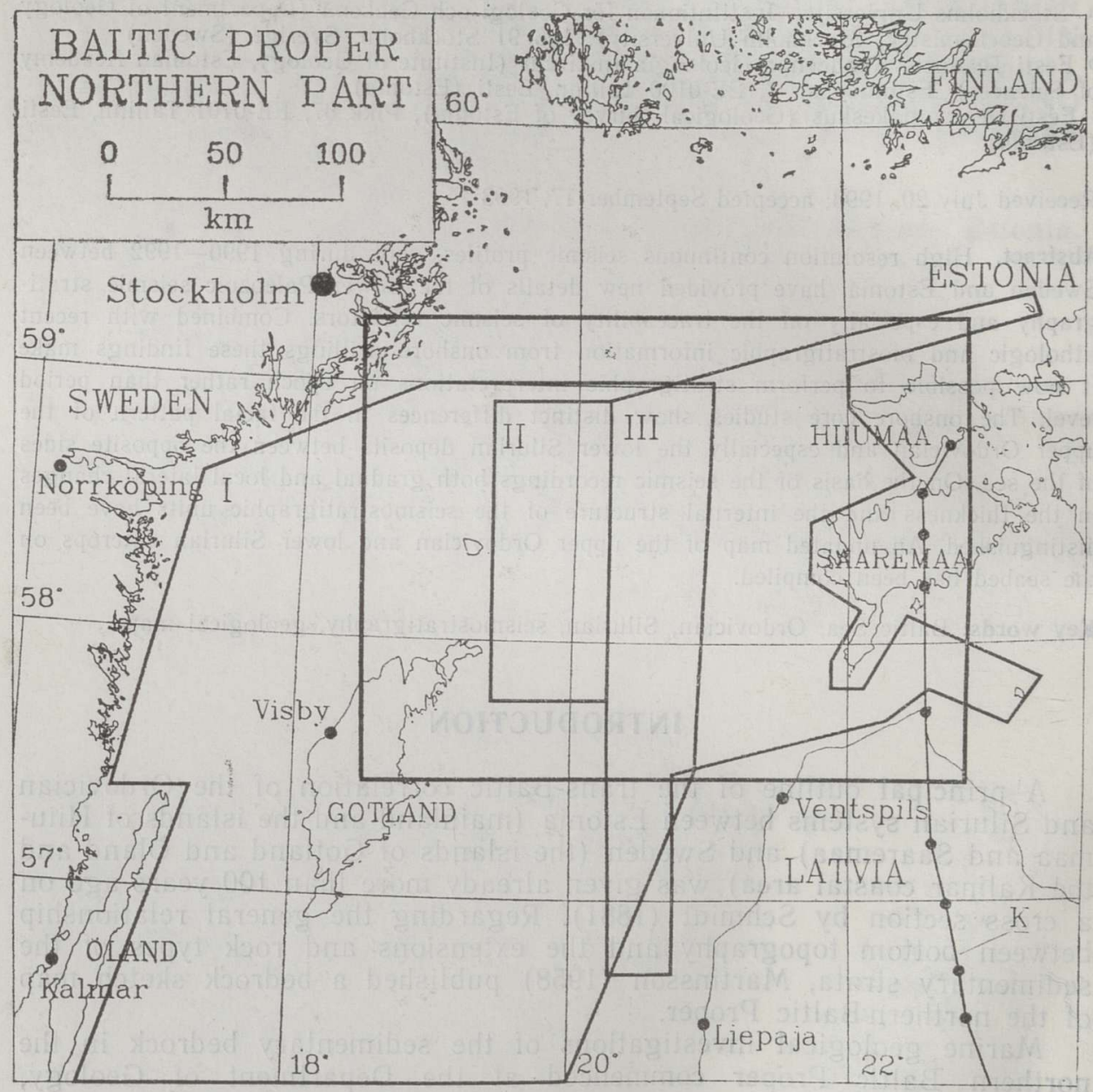

Fig. 1. Location map. I - the area surveyed in 1963-78, II - the area surveyed in 1990 , and III - the area surveyed in 1991-92. $K$ - location of the drill-core section from Hiiumaa to central Latvia (Кальо et al., 1991). 
In order to facilitate a firm connection of the Lower Paleozoic geology between Estonia and Sweden, a new set of high resolution continuous seismic reflection profiles was shot between Gotland and Hiiumaa-Saaremaa during 1990-1992. Some $700 \mathrm{~km}$ of profiles were shot in the Swedish zone and some $3000 \mathrm{~km}$ in the Estonian zone, using the geophysical equipment of the marine geological group of Tom Flodén. The study is performed in cooperation between Swedish and Estonian geologists. In order to simplify interpretation, the bulk of the profiles were orientated N-S to cross the E-W and NE-SW oriented outcrop zones of the Ordovician and Silurian stratigraphic units. For the purpose of seismostratigraphy the onshore bore-hole sections from Hiiumaa and Saaremaa islands, in the east, and Gotska Sandön and Gotland islands, in the west, were analysed (Fig. 2).

Recent information on the Ordovician-Silurian transition beds in Estonia, especially data on discontinuities and facial changes in connection with the Late Ordovician sea level fluctuations (Kaljo et al., 1988;

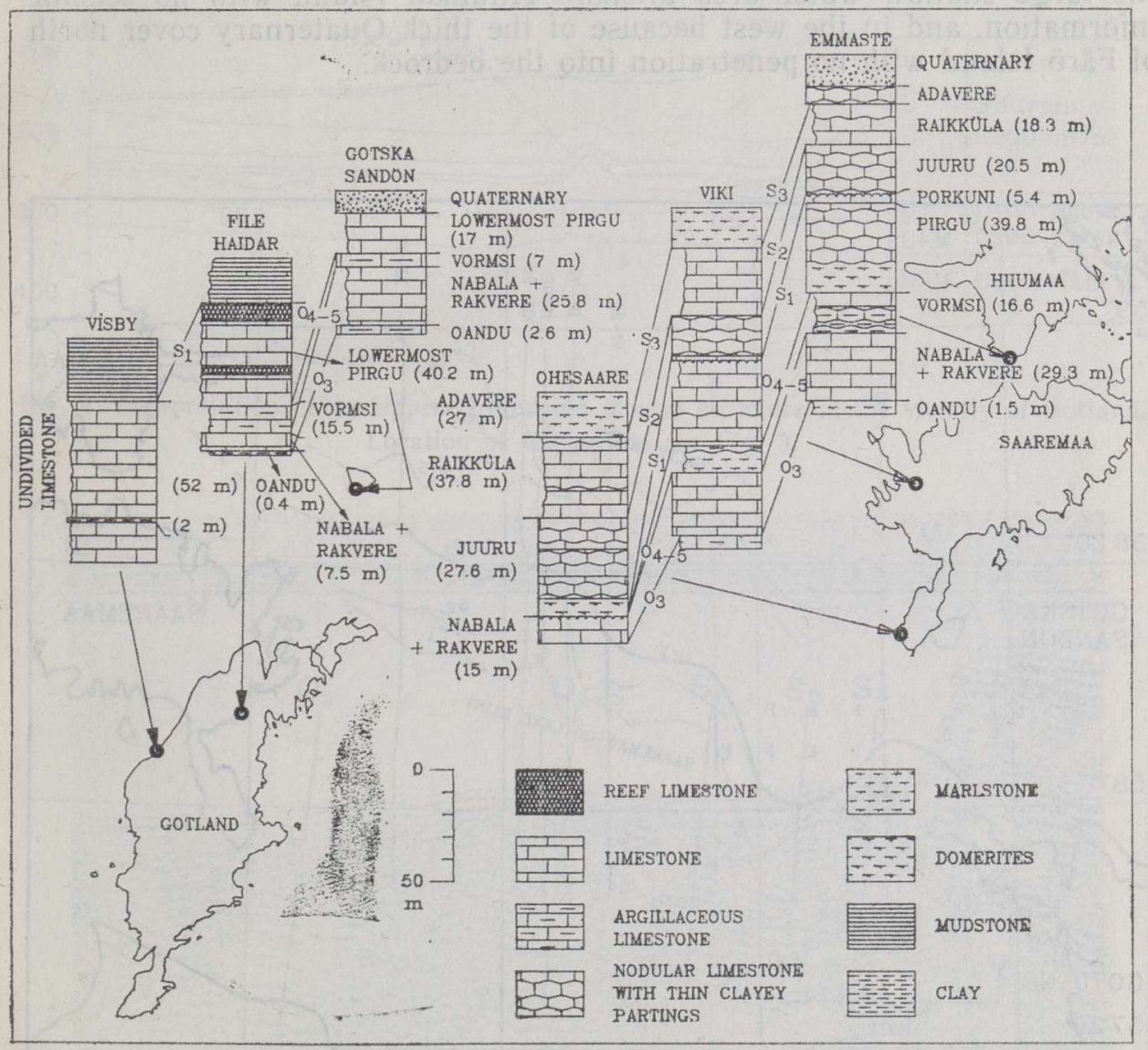

Fig. 2. Correlation and seismostratigraphic interpretation of drill-cores from Gotland and Gotska Sandön in Sweden, and from Hiiumaa and Saaremaa in Estonia. Probable seismic reflectors in the Ordovician-Silurian transition beds: $\mathrm{O}_{3}$ - the base of the Rakvere Stage, $\mathrm{O}_{4-5}$ - the base and the top of the Vormsi Stage, $\mathrm{S}_{1}$ - the Ordovician-Silurian boundary; tentatively in lower Silurian: $S_{2}$ - the base of the Raikküla Stage, and $S_{3}-$ the base of the Adavere Stage. 
Кальо et a1., 1991), was taken into consideration for the present study. New micropaleontological data on the upper Ordovician stratigraphy of Gotska Sandön and Gotland islands (Nõlvak \& Grahn, 1993) enabled us to specify the seismostratigraphy of Flodén (1980).

In this paper both previous and new seismic profiles have been used to trace the Ordovician-Silurian transition beds between Gotland and Hiiumaa islands (Fig. 3). The interpretation of the seismic recordings was promoted by the increased resolution in the new seismic profiles as well as by the recent detailed information on the Ordovician-Silurian boundary layers from the onshore core sections mentioned above. However, at least two circumstances have to be underlined which reduce the reliability of the interpretation proposed in this paper:

1. Lack of micropaleontological data on the Lower Silurian in the western onshore area, which brings about difficulties in precise transBaltic correlation of the Ordovician-Silurian boundary and the lowermost Silurian sequences.

2. Insufficiently convincing links between the bore-hole sections and the seismic profiling information near the coasts; in the east because of the large shallow water area offshore Hiiumaa Island with no seismic information, and in the west because of the thick Quaternary cover north of Fårö Island with no penetration into the bedrock.

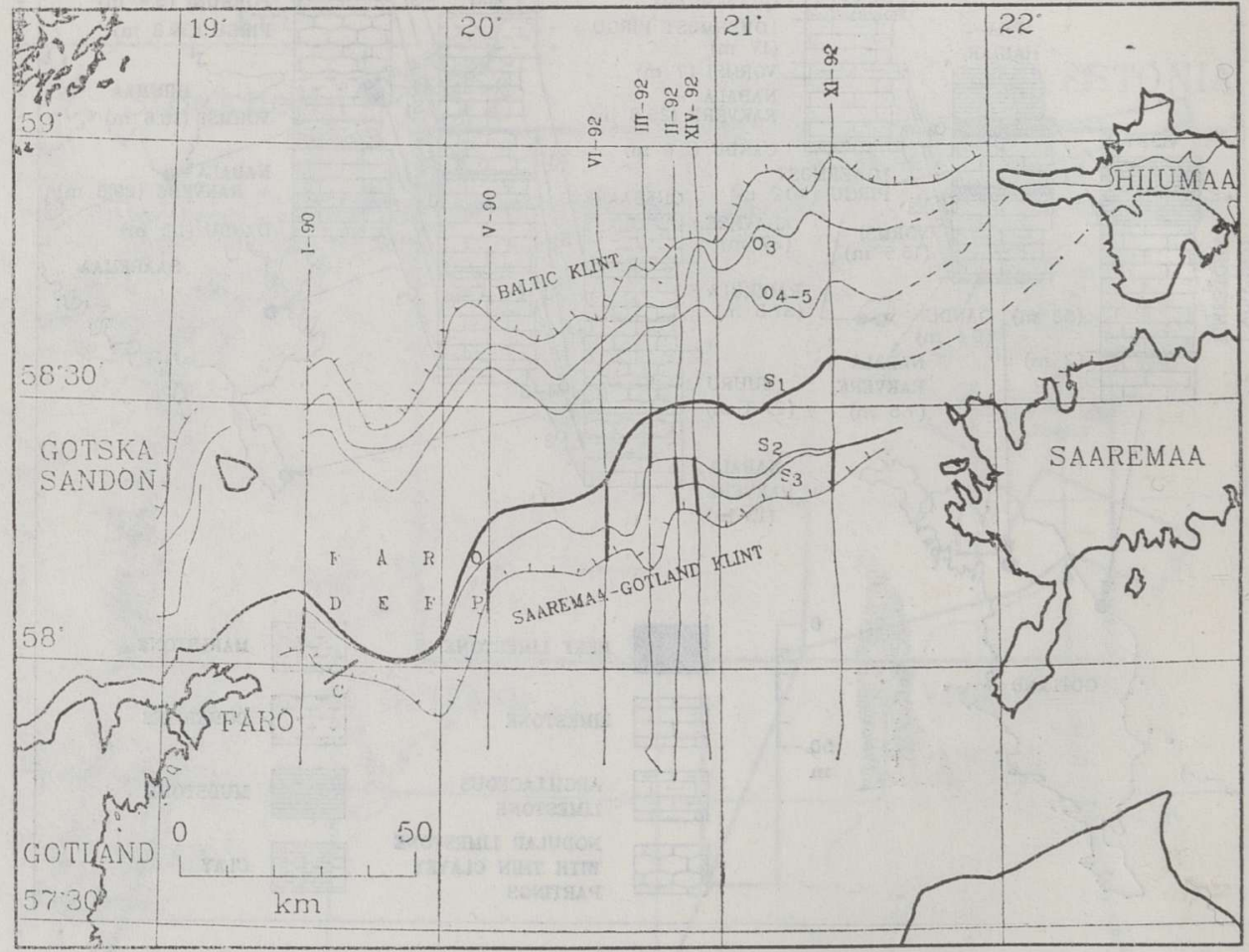

Fig. 3. The Ordovician-Silurian transition beds in the Central Baltic seabed between Gotland and Hiiumaa. The boundaries correspond to the reflectors in Fig. 2. I-90, VI-92 etc. - the identification numbers of the seismic profiles discussed in the text from the years of 1990, 1992, respectively. Locations of the parts of the profiles used as illustrations in Figs. $4-8$ are shown by bold lines. The Baltic and the Saaremaa-Gotland klints are shown by hatched lines. 


\section{GENERAL GEOLOGY}

The Ordovician-Silurian transition beds form a NE-SW orientated belt between the islands of Hiiumaa (Estonia), Gotland, and Gotska Sandön (Sweden).

The surface of the sub-Quaternary bedrock in the belt of outcropping Ordovician-Silurian transition strata sinks regularly in the SW direction from Hiiumaa Island to the Fårö Deep down to depths of some $200 \mathrm{~m}$ under the present sea-level of the Baltic. Further towards Fårö and Gotska Sandön, the transition zone rises again to about $100 \mathrm{~m}$ just north of Fårö Island. The topography of the top of the bedrock is generally flat, as the underwater klint in Cambrian-Ordovician deposits (the Baltic Klint) is situated to the NW, and the klint in Silurian (the Saaremaa-Gotland Klint) to the SE of the transition zone (Fig. 3). However, terraces in the bedrock topography up to $10-20 \mathrm{~m}$ high regularly mark lithological changes in the Ordovician, but rarely in the Silurian sequence. The

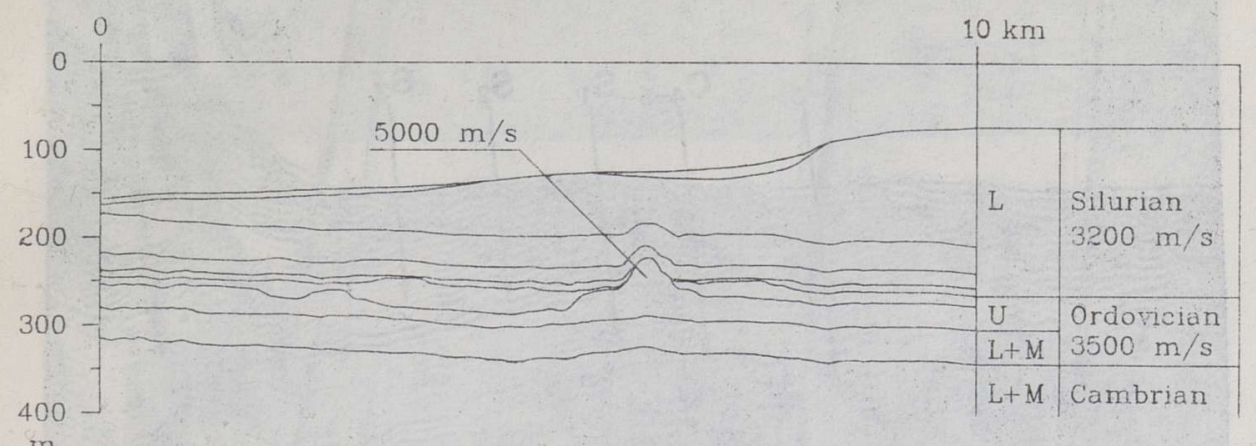

Fig. 4. Interpretation of an Upper Ordovician mound structure in the vicinity of Gotland. Location of the profile see Fig. 3.

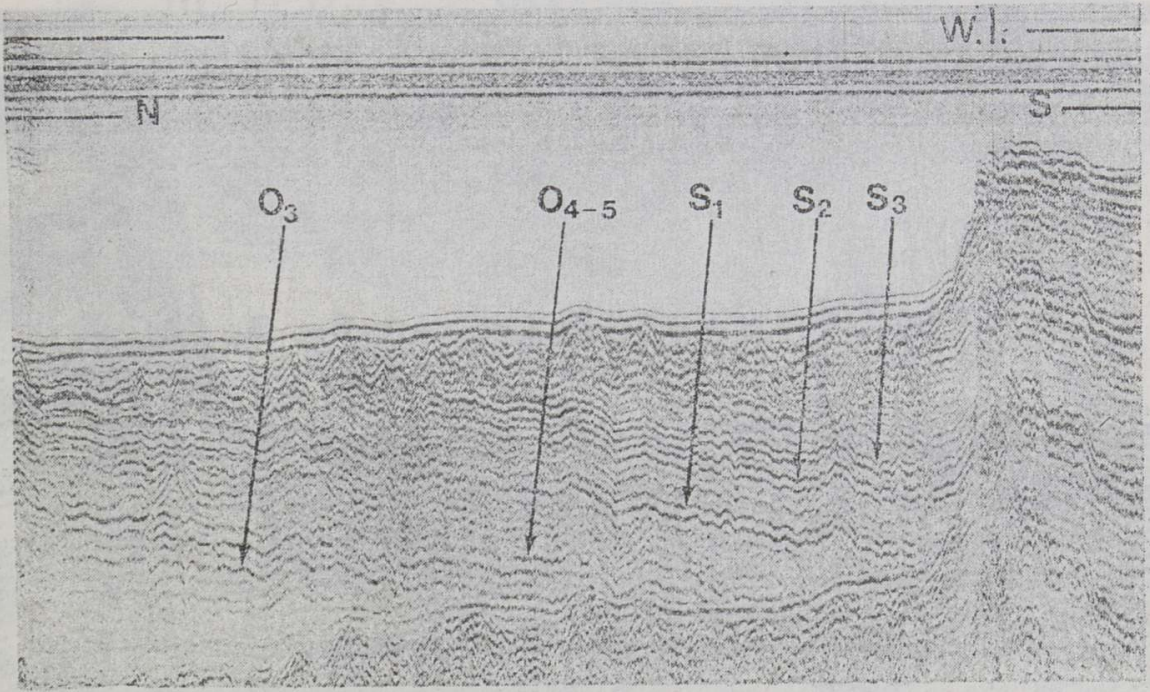

Fig. 5. Seismic profile XI-92 from north of the Saaremaa-Gotland Klint, offshore Estonia. Location of the profile see. Fig. 3.

Explanations to seismic diagrams: $\mathrm{O}_{3} \ldots \mathrm{S}_{2}-$ seismic reflectors (see Table). 
seismostratigraphic boundaries normally follow these escarpments. In the western part of the area, NE of Fårö Island, remarkable relief forms in the bedrock surface are created by carbonate mound structures of the late Ordovician age (Fig. 4).

The thickness of the Pleistocene glacial and postglacial deposits and the Holocene soft sediments in the northern Baltic Proper varies normally between 1 and $10 \mathrm{~m}$, locally reaching as much as $100 \mathrm{~m}$. As mentioned above, between Fårö and Gotska Sandön islands the glacial deposits are unusually thick, up to $100 \mathrm{~m}$, thereby concealing the Ordovician-Silurian transition beds in our recordings.

$A$

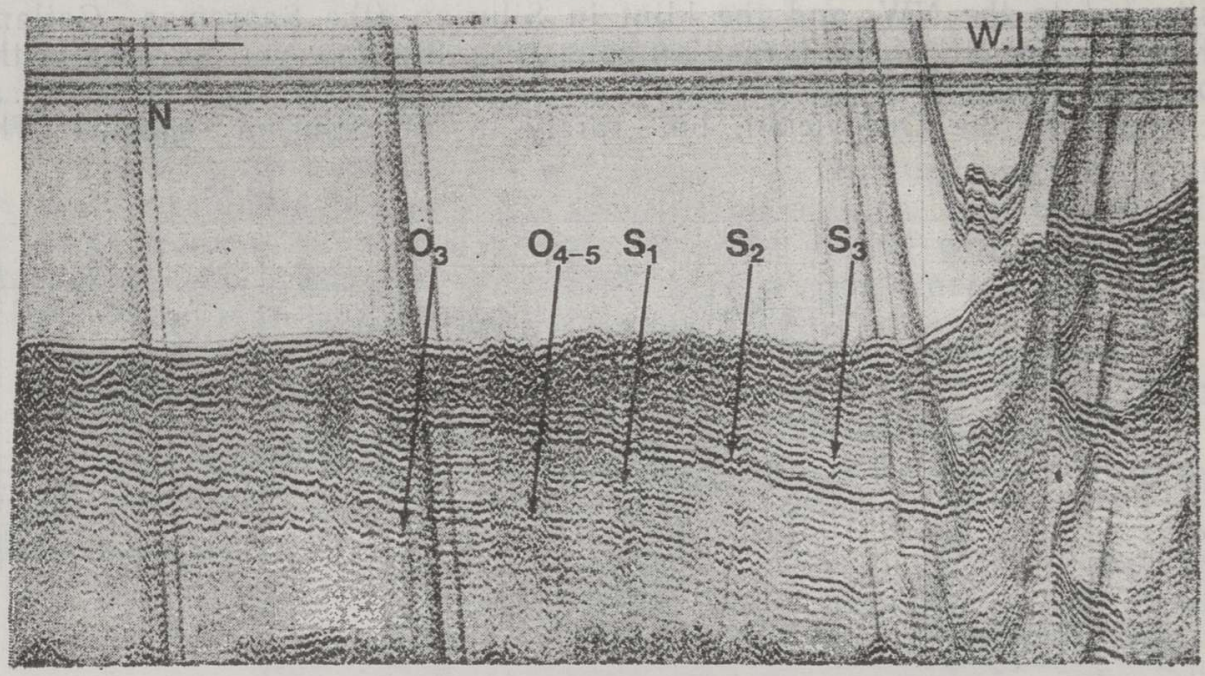

$B$

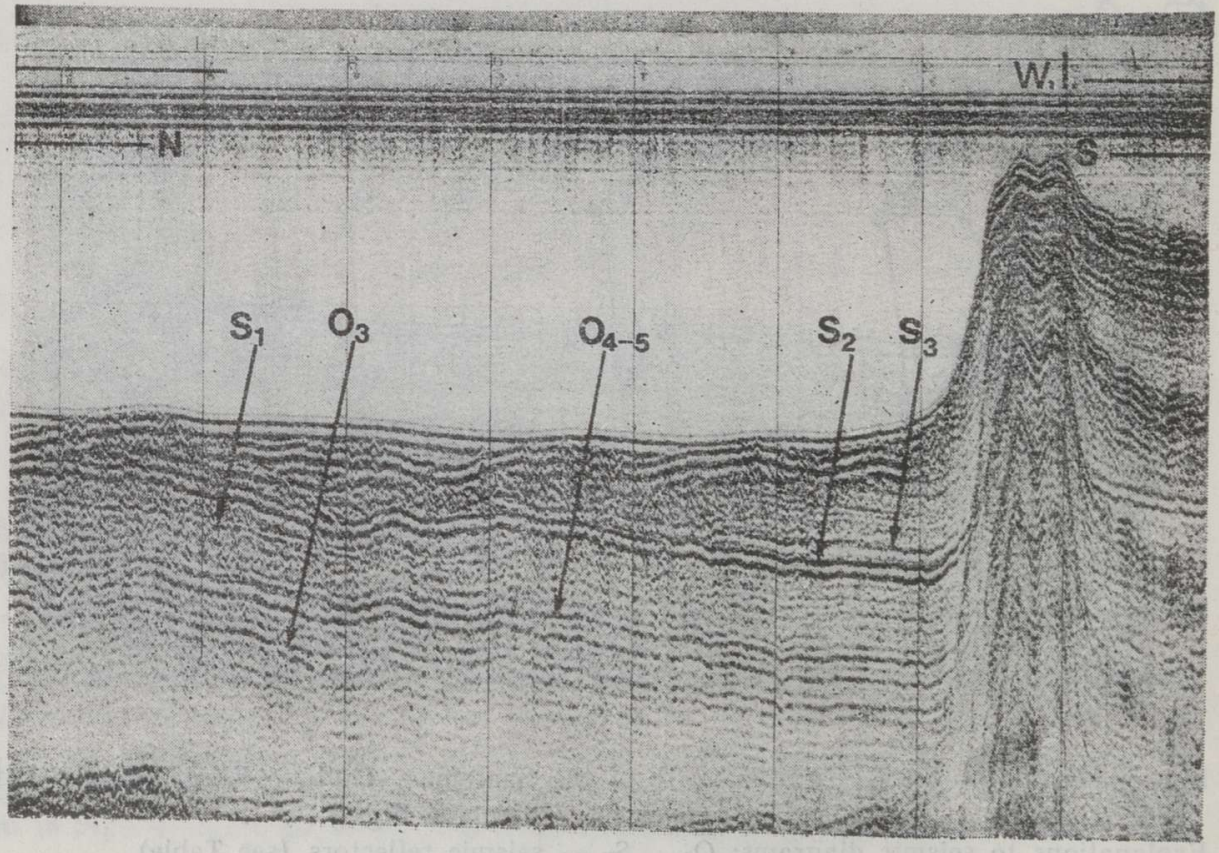




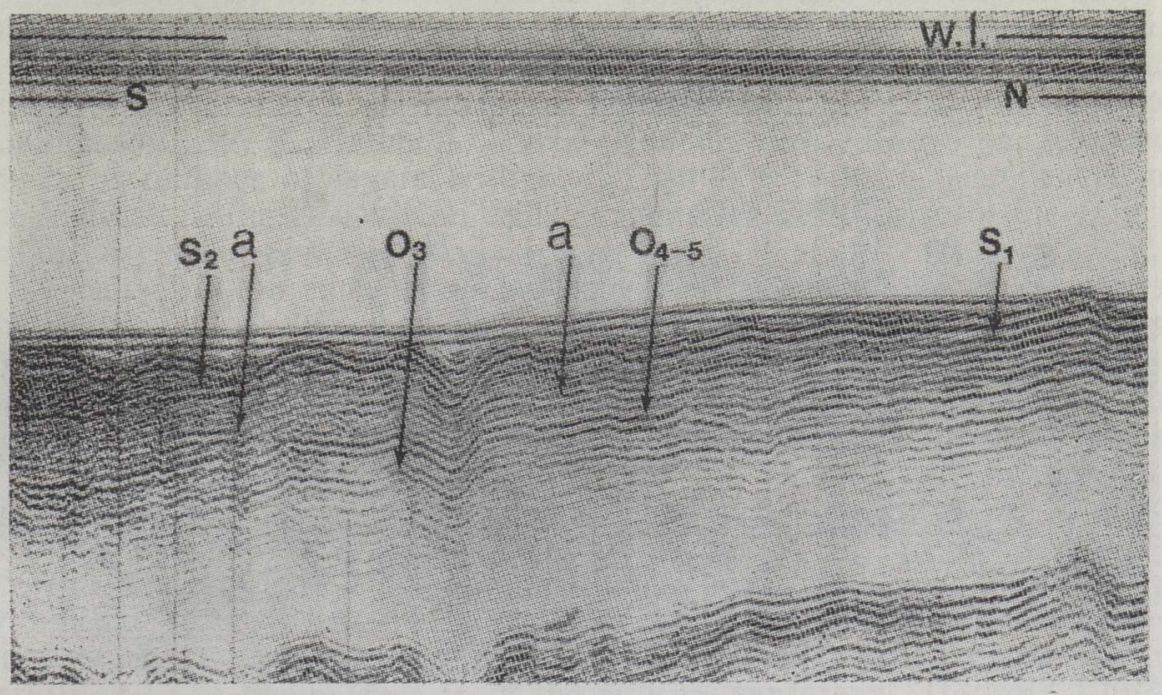

$D$

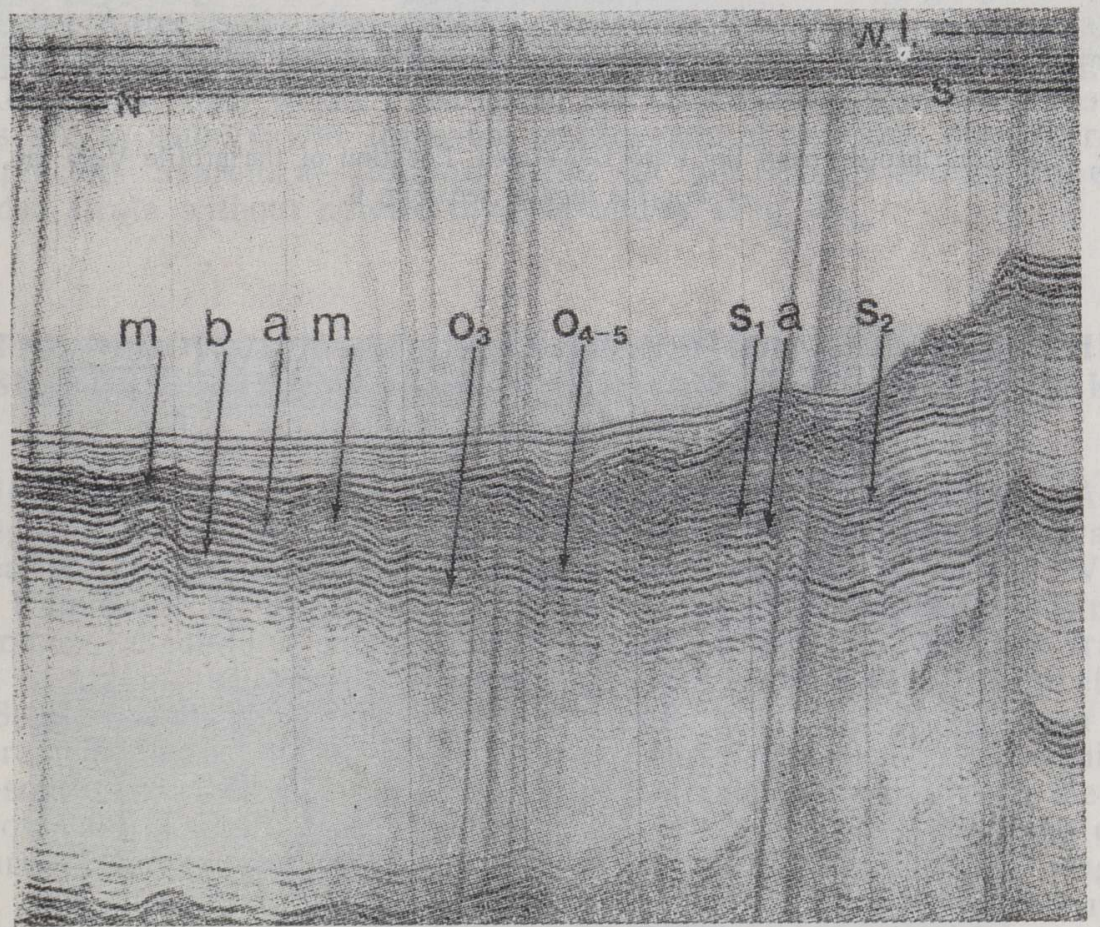

Fig. $6 A-D$. Seismic profiles from the transition area between the eastern and the western parts of the NE Baltic Proper demonstrating the facies changes in the NE-SW direction as revealed by changes in the seismic structure. Location of the profiles XIV-92, II-92, III-92 and VI-92 see Fig. 3.

$a$ - noncontinuous additional reflector in the Upper Ordovician, $b$ - local increase in the thickness of the Vormsi Beds, $m$ - carbonate mound, 


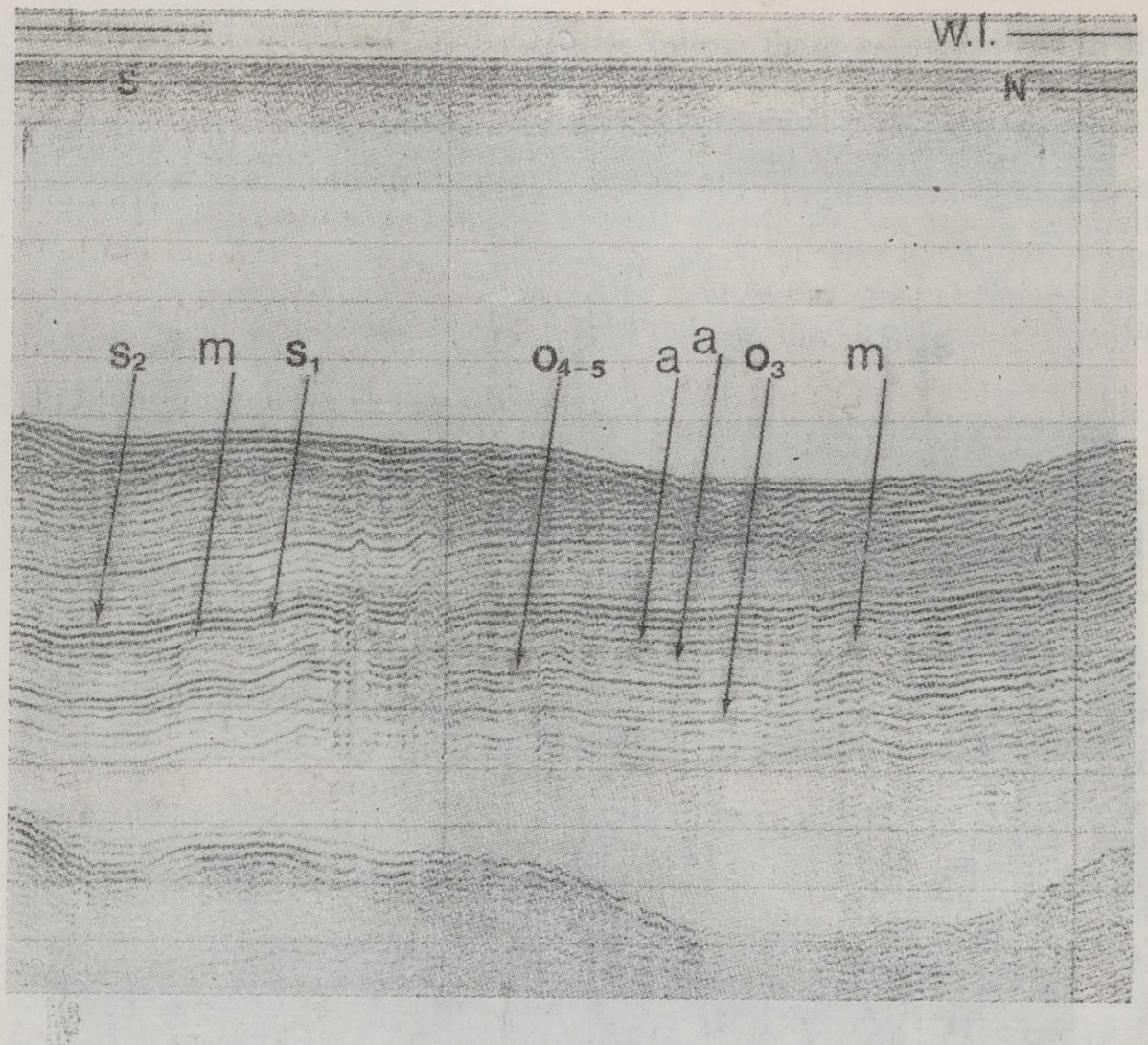

Fig. 7. Seismic profile from the Fårö Deep area. Location of the profile V-90 see Fig. 3. For the legend see .Fig. 6 .

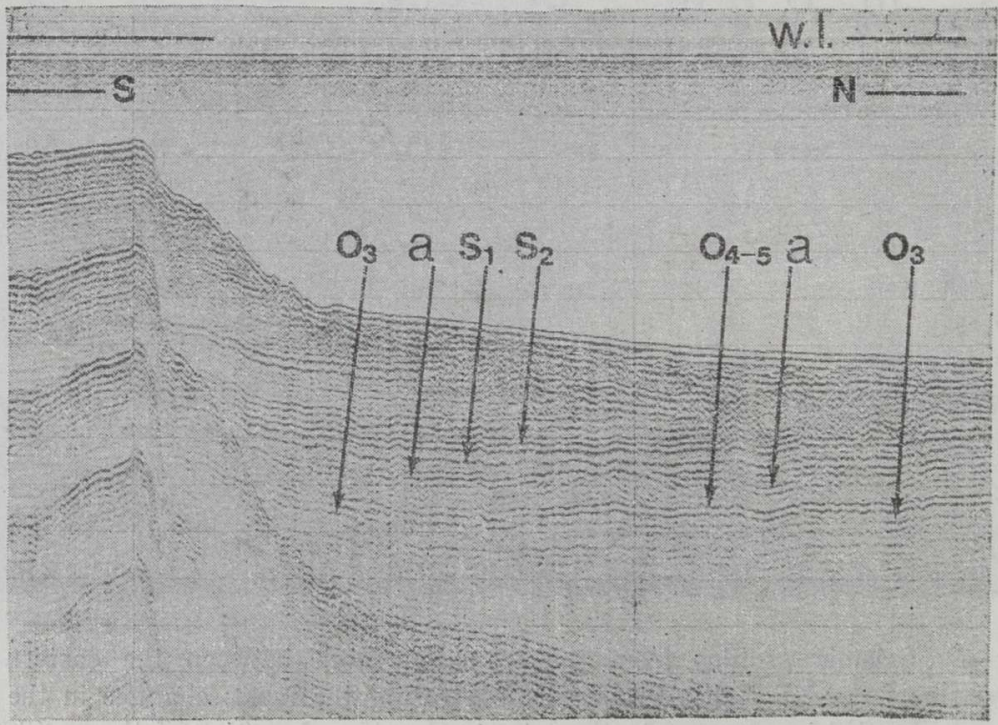

Fig. 8. Seismic profile offshore Färö Island. Location of the profile I-90 see Fig. 2. For the legend see Fig. 6 . 
The Ordovician and Silurian sedimentary rocks in the investigated area are mainly calcareous. They display rather high sound velocities and are usually poor in seismic marker surfaces. On the whole, both the Ordovician and the Silurian sedimentary basins had a facial zonality around the central part of the Baltic Syneclise. Comparatively shallowwater zones occurred in northern Estonia and northern Baltic Proper (Jaanusson, 1973; Мянниль, 1966; Кальо, 1970; Кальо \& Юргенсон, 1977). A number of layers with stable lithologies have been traced over large areas in the Ordovician and to a smaller extent also in the Silurian, useful as marker units in seismostratigraphy.

Because of the somewhat different orientations of the facial zones of the Baltic paleobasin, on the one hand, and the recent erosional submarine outcrop zone of the beds under description on the other hand, the lithologies of the Ordovician-Silurian strata undergo considerable changes in the NE-SW direction from Hiiumaa to Gotland. The changes in the NW-SE direction, i.e. down to the transitional zone of the paleobasin, are even more remarkable, especially in the Silurian. The latter changes will be discussed in a special paper.

The generally SSE-ward dipping reflectors of the Ordovician-Silurian transition beds are distinctly recorded in the seismic profiles within the zone of the outcropping Caradocian-Ashgillian and Llandoverian well stratified units northwards from the subsea Saaremaa-Gotland Klint. At the top of this Klint, the seismic penetration is very limited due to the hard limestone of the Jaagarahu Stage, which often contains large bioherms. Southwards from the uppermost edge of the Klint the penetration of the seismic pulse increases remarkably, but over a large part of this area the water is so shallow that the multiple reflector of the seafloor obliterates already the lowermost Silurian primary reflectors (Figs. 5, $6 A, 6 B, 7,8)$. Only in the Fårö Deep, the Ordovician-Silurian transition beds are to some extent traceable southwards of the low, deeply eroded by glaciers Saaremaa-Gotland Klint, in this section formed in evenbedded strata without noteworthy reef bodies (Fig. 7).

\section{THE ORDOVICIAN-SILURIAN TRANSITION STRATA ON THE ISLANDS OF HIIUMAA-SAAREMAA AND GOTLAND-GOTSKA SANDON}

In Estonia, and especially on the islands of the West Estonian Archipelago, the drilling programs and stratigraphic and paleogeographic research have yielded important new data during the last decade. Within the framework of the global investigation of the Ordovician-Silurian boundary, a complex detailed study of the Ordovician-Silurian transition strata of the NE Baltic region has been performed (Kaljo et al., 1988; Кальо et al., 1991). Along the cross-section from Hiiumaa and Saaremaa islands in the north to west Latvia and central Lithuania in the south, five facies belts have been distinguished through both the late Ordovician (Ashgill; Vormsi, Pirgu, and Porkuni stages) and the early Silurian (Lower and Middle Llandovery; Juuru and Raikküla stages). The area described in this paper coincides with the two northernmost facies belts.

In the extremely shallow-water facies belt on Hiiumaa Island (belt 1), cryptocrystalline, bioclastic, and biohermal limestones (with some lagoonal dolomites in the Raikküla Formation) occur. In the belt located on Saaremaa Island (belt 2), marls, cryptocrystalline, and biomicritic nodular limestones of considerably more offshore origin occur in the upper part of the transition zone to the deep areas of the basin. The belt located 


\begin{tabular}{l|l}
\hline $\begin{array}{l}\text { Probable } \\
\text { reflector }\end{array}$ & Stratigraphic level and lithological changes \\
\hline
\end{tabular}

$\mathrm{S}_{3}$

Boundary of Adavere $(\mathrm{H})$ and Raikküla $\left(\mathrm{G}_{3}\right)$ stages; strongly argillaceous limestones and marls $(\mathrm{H})$ overlie a complex of discontinuity surfaces in the upper part of the pure cryptocrystalline limestones $\left(\mathrm{G}_{3}\right)$

$\mathrm{S}_{2} \quad$ Boundary of the Raikküla $\left(\mathrm{G}_{3}\right)$ and Juuru $\left(\mathrm{G}_{1-2}\right)$ stages; pure limestones $\left(\mathrm{G}_{3}\right)$ cover the argillaceous limestones $\left(\mathrm{G}_{1-2}\right)$

$\mathrm{S}_{1} \quad$ Boundary of the Silurian and Ordovician $(\mathrm{O} / \mathrm{S})$; more or less argillaceous and nodular limestones of the Juuru stage $\left(\mathrm{G}_{1-2}\right)$ overlie the remarkable discontinuity surface of the sporadically pure reef limestones of the Porkuni stage $\left(F_{I I}\right)$

$\mathrm{O}_{4-5} \quad$ Boundaries of the Pirgu $\left(\mathrm{F}_{\mathrm{Ic}}\right)$-Vormsi $\left(\mathrm{F}_{\mathrm{Ib}}\right)$ and Vormsi-Nabala $\left(\mathrm{F}_{\mathrm{Ia}}\right)$ stages; the more argillaceous limestones and marls of the Vormsi Stage form a sharp lithological contact both with the overlying nodular limestones of the Pirgu and with the underlying cryptocrystalline limestones of the Nabala stages

$\mathrm{O}_{3}$

Boundary of the Rakvere $(E)$ and Oandu $\left(D_{I I I}\right)$ stages

along the Estonian-Latvian border zone (belt 3) is built up of marls and argillaceous limestones, formed on the gently tilted bottom of the basin.

Taking into consideration the most principal lithological changes between the Emmaste and the Viki core sections, the probable stratigraphic levels of the reflectors associated with the Ordovician-Silurian boundary are proposed (Table, Fig. 2).

The Gotska Sandön drill-core starts with an eroded Upper Ordovician sequence at the top, and the Visby and File Haidar drill cores descend from the central part of Gotland (Fig. 2), thus seawards in the paleobasin as compared to the submarine outcrop zone under discussion. Both the Ordovician and Silurian rocks belong to a deeper open shelf environment than the Hiiumaa sections.

A lithologically very sharp change from Ordovician limestone to Silurian mudstone and a distinctly pyritized corrosion surface at the top of the Ordovician have been described in both the Visby and the File Haidar cores (Thorslund \& Westergård, 1938). As proved by micropaleontological studies (Nōlvak, pers. comm.), the sharp discontinuity surface at the boundary marks a stratigraphic break: the second half of the Pirgu Stage is missing in File Haidar.

Below an attempt at a preliminary trans-Baltic seismostratigraphic correlation of the Ordovician-Silurian transition beds is made. The data obtained by the detailed study of the cores on Hiiumaa (Emmaste) and Saaremaa (Viki) are presented in the Table.

On Gotska Sandön and Gotland, like on Hiiumaa, a remarkable lithological change occurs at the level of the reflector $\mathrm{O}_{3}$. A $2.6 \mathrm{~m}$ thick unit of argillaceous limestone separates units of hard limestones in the Gotska Sandön core. This argillaceous limestone unit has been correlated with the Oandu Stage of Estonia (Мянниль, 1966, fig. 61). As within the eastern onshore area, the Oandu Stage thins out in the southward direction from Gotska Sandön to Gotland, reaching a thickness of merely $0.8 \mathrm{~m}$ 
in the File Haidar core. The overlying Rakvere and Nabala hard limestones are also comparable between the opposite onshore core sections. In both areas they decrease in thickness towards the south (Fig. 2).

About $15 \mathrm{~m}$ of argillaceous limestone followed by some $3 \mathrm{~m}$ of marly mudstone in the lower part of the upper Ordovician in the File Haidar core, and a $7 \mathrm{~m}$ argillaceous limestone layer in the Gotska Sandön core have been considered to be a stratigraphic equivalent of the Vormsi argillaceous limestone of Estonia (reflector $\mathrm{O}_{4-5}$ ). The about $40 \mathrm{~m}$ thick Pirgu limestone in the File Haidar core contains two up to $7 \mathrm{~m}$ thick reef limestone levels (Thorslund \& Westergård, 1938; Nōlvak, pers. comm.), which thus very likely yield additional seismic reflectors within the Pirgu Stage.

The lithologies of the lower Silurian sequences of the opposite coasts of the Baltic are highly contrasting. Instead of the intercalation of evenbedded and nodular limestones with marlstones/domerites in the eastern onshore core sections mudstones prevail in the western onshore sections (Fig. 2).

Just above the Ordovician pure limestone an about $15 \mathrm{~m}$ thick limestone layer intercalated with mudstone occurs in the lower Silurian of the Nystugu-1 well (OPAB Well Completion Report, 1981; Nystugu-1) on Fårö. Furthermore, a similar but somewhat thinner $(7 \mathrm{~m})$ and possibly also more argillaceous level of Silurian limestones has been described from the File Haidar core. Upwards in the latter core, the content of limestone lenses and nodules gradually decreases. Taking into consideration the File Haidar core, and also the Nystugu-1 well, a reflector in the lower Silurian north of Gotland should be expected at a level some $10-15 \mathrm{~m}$ above the Ordovician-Silurian boundary, between argillaceous limestone and mudstone with lenses and nodules of limestone.

Reflectors caused by probable hard limestone interbeds in the lower part of more than $100 \mathrm{~m}$ thick Llandovery and pre-reef Wenlockian mudstones and marls are of local extensions (Flodén, 1980). The reflector levels have not been strictly correlated to any biostratigraphically subdivided sections.

On the whole, two very probable reflector levels (see the Table) in the Middle and Upper Ordovician are expected as correlative across the Baltic Sea at least along the Upper Ordovician outcrop belt. On both coasts they occur as boundaries with sharp lithological contrasts.

The break at the Ordovician-Silurian boundary (reflector $\mathrm{S}_{1}$ ) has a different stratigraphic extension on the two opposite coasts and in the different parts of the seabed. Furthermore, changes in the lithologies of the beds underlying and overlying the boundary occur along the submarine section, which means that changes in the reflection character of the boundary are also expected to occur.

No lower Silurian marker surfaces have so far been correlated across the entire length of the submarine area.

\section{SEISMIC INTERPRETATION OF THE ORDOVICIAN-SILURIAN TRANSITION STRATA IN THE SEABED}

The Ordovician-Silurian transition strata outcrop in the seabed under glacial and postglacial deposits between the two submerged cliffs or klints of the northern Baltic Proper. The Baltic Klint is located north and the Saaremaa-Gotland Klint south of the Ordovician-Silurian boundary (Fig. 3). The Baltic Klint is formed in Ordovician limestone with Cambrian, and in the Gulf of Finland also Vendian, rocks in the cliff face, whereas the Saarema-Gotland Klint is entirely formed in 
lower Silurian rocks often with reef limestones at the crest and marly layers in the lowermost cliff face.

As expected from drill core data, at least two reflectors appear in the upper part of the Ordovician throughout the entire length of the submarine area from Hiiumaa to Gotska Sandön. These surfaces are in the present paper marked by indices $\mathrm{O}_{3}$ and $\mathrm{O}_{4-5}$.

The $\mathrm{O}_{3}$ reflector, located at the boundary of the Oandu argillaceous limestones and marls and the Rakvere cryptocrystalline limestones, is strong and persistent along the submarine outcrop from Hiiumaa in the $\mathrm{NE}$ to the Gotska Sandön area in the SW (Figs. 5, 6A, 6B, 6D, 7, 8). However, the Oandu beds, which are $3-4 \mathrm{~m}$ thick in the northern part, thin out southwards and the $\mathrm{O}_{3}$ reflector becomes continuously weaker in the same direction towards the Saarema-Gotland Klint and disappears sometimes already in front of it.

The double reflector $\mathrm{O}_{4-5}$ corresponds to both the upper and the lower sharp contacts of the argillaceous limestones and marls of the Vormsi Stage with the overlying nodular limestones of the Pirgu Stage and the underlying pure, in part cryptocrystalline, limestones of the Nabala Stage. The double reflector is present across the entire length of the submarine area, being one of the strongest reflectors there. However, because of the rather small thickness of the Vormsi Stage, $10-15 \mathrm{~m}$, and the seismic phase reversal at the Vormsi-Pirgu boundary, these two reflectors are only occasionally separated in the high resolution recordings. This is where the seismic signature of this double reflector deviates from the normal signature of the reflecting impulses (Figs. 5, 6A, 6B).

In the NE part of the submarine area, the thickness and evenly bedded structure of the unit $\mathrm{O}_{3}-\mathrm{O}_{4-5}$ are quite persistent along the outcrop zone. However, in the central parts of the submarine area the Vormsi argillaceous limestones locally increase in thickness, levelling out negative morphological forms in the subjacent beds (Fig. 6). Similar structural deviations were studied by Tuuling et al. in drill cores near the Assamalla buried monadnock structure in northern Estonia (see Нылвак, 1987). These structural deviations are well known in central Estonia. In the SW part of the submarine area, the reflector marks the base of limestones containing remarkable carbonate mound structures. Similar large mound structures above the Vormsi-Fjäcka level are well known from the upper Ordovician sections both on the Estonian and on the Swedish mainlands (Яануссон, 1979). In the seismic profiles offshore Gotland a continuous southwards thinning of the unit $\mathrm{O}_{3}-\mathrm{O}_{4-5}$ occurs (Fig. 8), which strikingly coincides with drill core data from Gotska Sandön, Gotland, and Estonia.

The reflector $S_{1}$, marking the Ordovician-Silurian boundary, is distinct in the eastern part of the submarine area where the $\mathrm{O}_{4-5}-\mathrm{S}_{1}$ unit is evenly bedded and stable in structure, and where this unit has similarities in lithology and thickness with the core sections on Hiiumaa. The Ordovician-Silurian transition strata have a regular southeastward dip here.

Just $\mathrm{E}$ of the area where the outcrop of the Ordovician-Silurian transition strata makes its first steep bend southwards (Fig. 3), marked changes in the seismic appearance of the upper Ordovician strata begin. Thus, from the profile XIV-92 and eastwards the Ordovician-Silurian boundary is clearly traceable (Figs. 3, 6A), whereas in the profile II-92, located closely $\mathrm{E}$ of this bend (Figs. 3, 6B), and in the next two profiles towards the W, III-92 and IV-92 (Figs. 3, 6C), the Ordovician-Silurian boundary reflection gradually almost disappears. The two reflectors above $\left(\mathrm{S}_{2}\right)$ and beneath $\left(\mathrm{O}_{4-5}\right)$ the Ordovician-Silurian boundary are distinct and uninterrupted across this submarine area (Figs. 6A, 6B, 6C, 6D). Although it is very weak, the Ordovician-Silurian boundary reflection is present far northwards from the Saarema-Gotland Klint (Figs. 6B, 
$6 C)$. Some structural complications in the transition strata, as compared with the evenly bedded internal structure of the strata further east, are also present here (Fig. 6C).

Westwards from the southward bend in the Ordovician-Silurian outcrop just mentioned, and up to the Gotska Sandön and Fårö coasts, a large number of carbonate mound structures occur. These mound structures resemble in their dimensions the Boda Limestone of Central Sweden (Jaanusson, 1963; Яануссон, 1979). The mounds are visibly larger in the northern part of the area, along the outcrop of the Pirgu rocks (reflector $\mathrm{O}_{4-5}$ in Fig. 3), where they are exposed by erosion and form remarkable elevations in the subsea bedrock surface. They commonly reach diameters of about $3 \mathrm{~km}$ here, but their original thicknesses are not measurable due to erosion. Southwards, in the direction of the Saaremaa-Gotland Klint and under a protective cover of lower Silurian rocks, they regularly become smaller, reaching diameters of merely $0.5-1 \mathrm{~km}$ and thicknesses of $20-$ $50 \mathrm{~m}$ (Figs $6 D, 7$ ). As an example, the calculated thicknesses and velocity changes of the seismostratigraphic unit $\mathrm{O}_{4-5}-\mathrm{S}_{1}$ and adjacent beds in the carbonate mound area $\mathrm{NE}$ of Fårö Island are given in Fig. 4. The internal structure of the upper Ordovician rocks within this carbonate mound area is much more complicated than further east (Figs. 6C, 6D). Abrupt appearance of reflectors in the Upper Ordovician is probably caused by several reef limestone levels in the western part of the sea as is the case in the File Haidar drill core on Gotland (Fig. 2).

The determination of the Ordovician-Silurian boundary reflector in the carbonate mound area is based on three circumstances: (1) the stratigraphic position of the carbonate mound structures, which can occur at different levels within the Pirgu Stage but never reach into the Silurian. In the case of the Boda Limestone the Ordovician-Silurian boundary always follows their top surfaces (Яануссон, 1979); (2) the generally notorious thickness of the Pirgu Stage in Gotland and West-Estonian drill cores (about $40 \mathrm{~m}$ ); and (3) the File Haidar drill core, where the first strong reflection within the Silurian is lithologically indicated to a level of some 15-20 $\mathrm{m}$ above the Ordovician-Silurian boundary.

To meet all the three requirements listed above, the Ordovician-Silurian boundary reflection in the western part of the sea has to be located somewhat beneath the first strong supposedly Silurian reflector, often just above the crest of the biggest buried carbonate mound structures (Figs. $6 D, 7)$. Because of interference the shape of this reflector is usually different from the normal shape of the reflected pulse, but it is strong enough to be easily traced in the profiles from closely offshore Gotland and across the Fårö Deep (Figs. 7, 8).

However, we also have to consider the fact that the stratigraphic break between the Ordovician and the Silurian rocks in the surrounding mainland areas can vary considerably, either the Pirgu rocks can be entirely lacking as in the Ohesaare drill core (Nõlvak \& Grahn, 1993, Fig. 2), or the lowermost Silurian almost up to the upper Llandovery can wedge out over the crests of the carbonate mound structures as for the Boda Limestone (Яануссон, 1979). The latter break is probably caused by nonsedimentation on the subsea elevations as Llandovery sediments fill the space between the mound structures (Яануссон, 1979). Although the measurable thicknesses of the buried mound structures NE of Fårö Island are not comparable with those of the Boda Limestone, which may be up to $100 \mathrm{~m}$ thick, the possibility that also in the Baltic Sea the space between mound structures is partially infilled by early Silurian sediments cannot be excluded. Thus, the exact location of the Ordovician-Silurian boundary in the SW part of the presently investigated area is still rather problematical. 
The lithologies of the lower Silurian, Llandovery, and Wenlock are quite different in the opposite onshore areas of the northern Baltic Proper. As mentioned above, there are no biostratigraphic data for a detailed correlation of the lowermost part of the Silurian between the Gotland, which lacks outcrops, and the Hiiumaa Island-Estonian mainland areas.

The principal lithological changes of the biostratigraphic units in the Lower Silurian are best demonstrated by the changes along the Saaremaa-Gotland Klint. Thus, the dolomitic limestones of the Ninase Member form most of the Klint face in the Saaremaa part of the Klint. The uppermost crest here is often formed by limestones with abundant reef bodies of the Vilsandi Beds. These units belong to the topmost part of the Jaani and the lowermost part of the Jaagarahu Stage respectively, whereas the Upper Visby Marls and the Högklint Limestone with reef structures in the Gotland part of the Klint are correlated with the lowermost part of the Jaani Stage. The reflectors corresponding to the lithologic contrast between the more than $100 \mathrm{~m}$ thick mainly marlstone-mudstone deposits and the overlying limestone-dolomite complex would therefore not have a synchronous biostratigraphic position. Quite a large number of reflectors recorded in the Llandoverian and lower to middle Wenlockian part of the sequence have no biostratigraphic dating yet (Figs. 6D, 7, 8).

Nevertheless, two constant strong reflectors within the Lower Silurian of the eastern part of the sea are clearly distinguishable westwards up to profile XIV-92 (Figs. 5, 6A). Unfortunately, there is no seismic information just offshore Estonia due to the shallow waters, but most likely these two very sharp reflectors are connected with the lithologically very contrasting boundaries on the Estonian mainland between the Juuru-Raikküla (reflector $\mathrm{S}_{2}$ ) and the Raikküla-Adavere (reflector $\mathrm{S}_{3}$ ) stages. However, the extremely rapid facial changes in the Lower Silurian force us to take a very cautious attitude towards any geochronological correlations of them.

Some fluctuations in the thickness of the unit $S_{2}-S_{3}$ are perceptible. The reflections at the unit boundaries fluctuate, too. The $S_{3}$ reflector, which is stronger than the $S_{2}$ reflector in the eastern part of the area, diminishes gradually in strength towards the $\mathrm{W}$. Thus, the $\mathrm{S}_{2}$ reflector becomes the strongest bedrock reflector in the central part of the investigated area.

As in the case of the Ordovician-Silurian boundary reflector, remarkable changes both in the $S_{2}$ and $S_{3}$ reflectors and in the units $S_{1}-S_{2}$ and $\mathrm{S}_{2}-\mathrm{S}_{3}$ take place westwards beginning from the profile II-92 (Fig. 3). The thickness of the unit $S_{2}-S_{3}$ decreases to the extent that $S_{3}$ becomes scarcely distinguishable (Fig. 6B) and also the thickness of the unit $S_{1}-S_{2}$ decreases so that in the seismic profiles from the western part of the research area the Ordovician-Silurian boundary reflector and the lowermost reflector in the Silurian form a very strong pair of two interfacing reflectors (Figs. 7,8 ).

The map (Fig. 3) demonstrates the outcrop locations of the geological boundaries which correspond to the reflectors just described. In the area between Gotska Sandön and Gotland, the position of the OrdovicianSilurian boundary has not changed significantly as compared to the map of Flodén (1980). East of the Fårö Deep, on the other hand, considerable changes have occurred. This is partly due to the fact that the easternmost part of the Ordovician-Silurian transition zone was not studied at all in 1980 .

On the whole, the correlation of the offshore seismic diagrams with onshore drill core data has given a quite new interpretation of the middle and upper parts of the Ordovician on the seafloor. For a similar subdivision of the overlying lower Silurian beds, much work remains to be carried out. Thus, the reflectors in the lower Silurian $\left(S_{2}\right.$ and $\left.S_{3}\right)$ shown on the map (Fig. 3) have no biostratigraphic dating. 


\section{DISCUSSION}

A complete interpretation of the Ordovician sequence was given by Flodén (1980). Owing to the low resolution in the seismic profiles, rarely more than one internal reflector was recorded in the Ordovician (Flodén, 1980 , p. 105). Using new equipment in 1990-1992, high resolution profiles were obtained and internal reflectors in both the lower and the upper Ordovician seismostratigraphic units of Flodén (1980) were subdivided. These new reflectors are of marker quality, and as a result of correlations with biostratigraphically studied core sections onshore their stratigraphic positions are well defined: $\mathrm{O}_{3}$ corresponds to the Oandu-Rakvere boundary (reflector $\mathrm{O}_{2}$ of Flodén, 1980) and $\mathrm{O}_{4-5}$ corresponds to the VormsiPirgu boundary. The latter boundary appeared only occasionally in the old profiles, and was not defined as a marker surface then.

The more precise subdivision of the upper part of the Ordovician offers good possibilities for studying internal sedimentary structures. In the eastern part of the investigated area, the unit $\mathrm{O}_{3}-\mathrm{O}_{4-5}$ is characterized by a generally even-bedded build-up of the strata despite of small mound structures in places. Structurally, it resembles the build-up of these stages in the northern and central parts of Estonia. In the central and western parts of the area, the unit increases in thickness and has undulating internal structures because of changes in the Nabala and Vormsi thicknesses.

The most remarkable changes from the east to the west appear in the upper Ordovician unit $\mathrm{O}_{4-5}-\mathrm{S}_{1}$ and in the lowermost part of the Silurian. Whereas the quite evenbedded unit $\mathrm{O}_{4-5}-\mathrm{S}_{1}$ lacks internal seismic structures offshore of Hiiumaa, it contains complicated mound-influenced structures with a few disconnected often undulating reflectors offshore of Gotland. The carbonaceous lowermost Silurian in the Estonian mainland becomes argillaceous westwards, and loses its trichotomy $\left(\mathrm{S}_{1}-\mathrm{S}_{2}-\mathrm{S}_{3}\right)$ in the central part of the investigated area.

Perceptible clearly in the seismic profiles, the changes in the thickness and internal structure from the east to the west of the Ordovician-Silurian transition beds take place in the central part of the investigated area. The changes occur where the outcrop zone of the units makes its first remarkable bend southwards (Fig. 3), and where consequently an abrupt deepening of the bedrock surface occurs. This deepening of the bedrock surface is possibly in part inherited from the preglacial erosional topography and in part a result of glacial erosion. In any case, the erosion has followed the distinct changes in lithology both in the upper Ordovician and especially in the lower Silurian sequences between the eastern and western parts of the investigated area (Fig. 4). This allows us to assume the existence of a dynamic deep crustal structure in the middle of the investigated area causing changes in the condition of the sedimentation in the late Ordovician to early Silurian basin between its eastern and western parts.

The seismic studies in the zone of the Ordovician-Silurian transition beds have enabled us to trace the stratigraphic markers in the seabed and to investigate the internal structure of the units, including their thicknesses. The data obtained prove the general idea of the facial zonality in the Baltic paleobasin (Jaanusson, 1973; Мянниль, 1966). Moreover, the seismic diagrams contain information for mapping the facies zones through the sea and for microfacial analysis of details impossible to appreciate on the basis of the rare core sections on the mainland. 


\section{ACKNOWLEDGEMENTS}

We thank the crews of $\mathrm{R} / \mathrm{V}$ Strombus, R/V Livonia (previously A. Veimer), and Prof. Multanovski for assistance in various respects during the field trips.

Thanks are due to Valdar Jaanusson for valuable consultation in stratigraphy and geology of the Cambro-Silurian of the Baltoscandian region. Jaak Nõlvak, at present involved in the investigation of core sections for the trans-Baltic correlation of Ordovician, participated several times in discussions of results obtained by marine research and critically read the manuscript of this paper. Tarmo Kiipli shared his experience in the Ordovician seismostratigraphy in the light of previous work in the eastern Baltic Proper. We thank referee D. Kaljo, who contributed with useful suggestions.

Financial support for the project has been provided by the Estonian Academy of Sciences, the Swedish Academy of Sciences, the Swedish Institute, the Estonian Science Foundation, the Estonian Innovation Foundation, the Stockholm University, and the Estonian Geological Survey.

\section{REFERENCES}

Flodén, T. 1975. Seismic refraction soundings in the area around Gotland, central Baltic.-Stockholm Contributions in Geology, 28, 2, 9-43.

Flodén, T. 1980. Seismic stratigraphy and bedrock geology of the central Baltic.-Stockholm Contributions in Geology, 35, 1-240.

Flodén, T. 1981. Current geophysical methods and data processing techniques for marine geological research in Sweden.-Stockholm Contributions in Geology, 37, 5, 49-66.

Jaanusson, V. 1963. Classification of the Harjuan (Upper Ordovician) rocks of the mainland of Sweden.-Geol. Fören. Stockh. Förh., 85, 1, 110-144.

Jaanusson, V. 1973. Aspects of carbonate sedimentation in the Ordovician of Baltoscandia. - Lethaia, 6, 1, 11-36.

Kaljo, D., Nestor, H., Põlma, L. 1988. East Baltic Region. - In: Cocks, L. R. M. and Rickards, R. B. (eds.). A global analysis of the Ordovician-Silurian boundary. Bull. British Museum of Natural History (Geology), 43, 85-91.

Martinsson, A. 1958. The submarine morphology of the Baltic Cambro-Silurian area. Bull. Geological Institutions of the University of Uppsala, 38, 1, 11-35.

Nölvak, J. and Grahn, Y. 1993. Ordovician Chitinozoan zones from Baltoscandia. - Rev. Palaeobot. Palyn. (Amsterdam), 79, 245-269.

OPAB Well Completion Report. 1981. Geol. Survey of Sweden, Uppsala.

Schmidt, Fr. 1881. Revision der ostbaltischen silurischen Trilobiten nebst geognostischer Ubersicht des ostbaltischen Silurgebiets. Abt. 1. - Mem. Acad. Sci. St. Petersb., Ser. $7,30,1$.

Thorslund, P. and Westergärd, A. H. 1938. Deep boring through the Cambro-Silurian at File Haidar, Gotland. - Sveriges Geologiska Undersökning, C 415, 5-56.

Григелис А. А. (ed.). 1991. Геология и геоморфология Балтийского моря. Объяснительная записка к геологическим картам м-ба 1:500 000. Недра, Ленинград.

Кальо Д. (еd.). 1970. Силур Эстонии. Валгус, Таллинн.

Кальо Д., Юргенсон Э. 1977. Фациальная зональность силура Прибалтики. - In: Қальо Д. Л. (ed.). Фации и фауна силура Восточной Прибалтики. АН ЭССР, Ин-т геол., Таллинн, 122-148.

Кальо Д. Л., Нестор Х. Э., Пылма Л. Я., Эйнасто Р. Э. 1991. Позднеордовикское оледенение и его отражение в осадконакоплении Палеобалтийского бассейна. - In: Важнейшие биотические события в истории Земли. АН Эстонии, Таллинн, $68-78$.

Мянниль Р. М. 1966. История развития Балтийского бассейна в ордовике. Валгус, Таллинн. 
Нылвак Я. 1987. Раквереский, набалаский, вормсиский и пиргуский горизонты. In: Пуура В. (еd.). Геология и полезные ископаемые Раквереского фосфоритоносного района. Валгус, Таллинн, 63-69.

Яануссон В. 1979. Қарбонатные постройки в ордовике Швеции. - Изв. АН Каз. ССР. Сер. геол., 4-5, 92-99.

\title{
ORDOVIITSIUMI JA SILURI PIIRIKIHID MEREPŌHJAS GOTLANDI JA HIIUMAA VAHEL
}

\author{
Tom FLODEN, Väino PUURA, Per SÖDERBERG, Igor TUULING, \\ Kalle SUUROJA
}

Suure lahutusvõimega seismoakustilised profiilid teaduslike uurimislaevade «Strombus», «Livonia» (varem «A. Veimer») ja «Prof. Multanovski» 1990.-1992. aasta uurimisreisidelt Läänemere põhjaossa võimaldasid saada uusi andmeid ordoviitsiumi ja siluri piirikihtide levikust, seismostratigraafiast ja siseehitusest. Merepōhja ehituse interpretatsiooniks kasutati mere vastaskallastelt puuritud südamike uurimise tulemusi. Seismilised peegelduspinnad, mida on võimalik jälgida kogu mere põhjaosas, vastavad litoloogiliste muutustega ja katkestuspindadega markeeritud stratigraafilistele piiridele keskordoviitsiumis, ülemordoviitsiumis ning ordoviitsiumi ja siluri piiril. Kaks alamsiluri peegelduspinda on jälgitavad vaid mere idaosas. Seismoprofiilidel on täheldatav kihtide paksuse ja siseehituse pindalaline muutumine. Saadud tulemused võimaldavad oluliselt täiendada hilisordoviitsiumi ja varasiluri avamuste ja faatsieste leviku pilti nüüdisaegse Läänemere põhjas.

\section{ПОГРАНИЧНЫЕ СЛОИ ОРДОВИКА И СИЛУРА НА ДНЕ МОРЯ МЕЖДУ ОСТРОВАМИ ГОТЛАНД И ХИИУМАА}

\section{Том ФЛОДЕН, Вяйно ПУУРА, Пер СЕДЕРБЕРГ, Игорь ТУУЛИНГ, Калле СУУРОЯ}

Сейсмоакустические диаграммы, снятые аппаратурой с высокой разрешающей способностью с бортов НИС «Стромбус», «Ливония» и «Проф. Мултановский» за 1990-1992 гг. в северной части Балтийского моря, позволили получить новые данные о распространении, сейсмостратиграфии и внутреннем строении пограничных слоев ордовика и силура. В целях интерпретации строения морского дна использованы результаты изучения разрезов прибрежных скважин. Сейсмические отражающие поверхности, наблюденные на дне моря, скоррелированы с определенными литологическими границами в разрезе среднего-верхнего ордовика и на границе ордовика-силура. Две поверхности отражения в нижнем силуре прослежены только в восточной части моря. На сейсмограммах видны латеральные изменения мощности и строения слоев. Полученные данные позволяют уточнить карту выходов и фациальный состав слоев. 